\title{
Atmospheric Dispersion Modeling of the Emissions from the Logbaba Thermal Power Plant, Douala-Cameroon
}

\author{
R. Mbiaké1, E. Mfoumou'2, A. Beya Wakata3 ${ }^{3}$ E. Ndjeuna4, J. R. Kaze Djamen ${ }^{5}$, R. Leduc ${ }^{6}$, C. Bobda7 \\ ${ }^{1}$ Faculty of Sciences, University of Douala, Douala, Cameroon \\ ${ }^{2}$ Division of Applied Research, Nova Scotia Community College, Dartmouth, Canada \\ ${ }^{3}$ Faculty of Sciences, University of Yaoundé, Yaoundé, Cameroon \\ ${ }^{4}$ Ecole Normale Supérieure d'Enseignement Technique (ENSET), Douala, Cameroon \\ ${ }^{5}$ Centre de Physique Atomique, Moléculaire Optique et Quantique (CEPAMOQ), Douala, Cameroon \\ ${ }^{6}$ AirMet Science Inc., Quebec, Canada \\ ${ }^{7}$ Department of Public Health, University of San Diego, San Diego, CA, USA \\ Email: rmbiake@yahoo.fr, rmbiake85@gmail.com
}

How to cite this paper: Mbiaké, R., Mfoumou, E., Wakata, A.B., Ndjeuna, E., Djamen, J.R.K., Leduc, R. and Bobda, C. (2017) Atmospheric Dispersion Modeling of the Emissions from the Logbaba Thermal Power Plant, Douala-Cameroon. Open Journal of Air Pollution, 6, 117-134.

https://doi.org/10.4236/ojap.2017.64010

Received: August 22, 2017

Accepted: November 7, 2017

Published: November 10, 2017

Copyright (c) 2017 by authors and Scientific Research Publishing Inc. This work is licensed under the Creative Commons Attribution International License (CC BY 4.0).

http://creativecommons.org/licenses/by/4.0/

\begin{abstract}
Air quality in the vicinity of the thermal power plant of Logbaba in the town of Douala was investigated in this study using data collected in a 5-year period (2008-2012). The distribution of pollutants such as $\mathrm{SO}_{2}, \mathrm{NO}_{x}, \mathrm{CO}$ and the particle matter $\mathrm{PM}_{2.5}$ was analyzed using numerical modeling, based on physical and thermal characteristics, as well as the operating periods of the power plant. The American Environmental Regulator Model (AERMOD) that is an atmospheric dispersion model was used for simulation. The wind rose and others National Oceanic Atmospheric Administration (NOAA) in-situ data were used for the validation of the model. The pollutants distribution was evaluated at two locations: the exit of the power plant, considered as reference point, and at $330 \mathrm{~m}$ away from the exit where the first houses appeared. The results show that the relative concentration for each contaminant at the exit of the power plant is $7.2 \%$ for the $\mathrm{PM}_{2.5}$ during 24 hours of emission, $46.0 \%$ for $\mathrm{CO}$ over 8 hours of emission, and $17.5 \%$ for $\mathrm{SO}_{2}$ over one hour. The $\mathrm{NO}_{\mathrm{x}}$ is the highest pollutant with $259.1 \%$ over an hour of emission and $51.0 \%$ over one year. Beyond $330 \mathrm{~m}$ of the power plant, only $\mathrm{NO}_{\mathrm{x}}$ keeps a polluting character with a relative rate of $100 \%$. These results show that the pollution level of the power plant is over the threshold for air quality set by the World Health Organization. Moreover, among all pollutants investigated, $\mathrm{NO}_{\mathrm{x}}$ appears to be the most critical for the population in the vicinity of the Logbaba thermal
\end{abstract}


power plant. This information is therefore important for policy and decision makers in preventing the vulnerability of the population to air pollutants from such industrial settings.

\section{Keywords}

AERMOD, Pollutants, Air Quality Model, Relative Concentration, Thermal Power Plant

\section{Introduction}

Most atmospheric pollutants emitted naturally or from human activities, have been known to have adverse effects both on human health (Bünger et al., 2012 [1]; Olsson et al., 1999 [2]) and ecosystems (Bell et al., 2004 [3]). They are also the cause of climate change (Doek-Rae Kim et al., 2015 [4]) in the form of greenhouse gas emission. Their release considerably affects air quality which becomes therefore stagnant, thick and troublesome (Sportisse, 2004 [5]). The pollutants with varying atmospheric lifetime are either atmospheric particulate matters or traces of gaseous molecules, and their accumulation and dispersion mainly depend on the existing sources, the meteorological conditions and local topography. In order to evaluate their rate, in-situ measurements or the use of predictive numerical models are needed. In most sub-Saharan countries air pollution is tragic. The World Health Organization (WHO) reported that, air pollution is a major environmental risk to health causing about 1.3 millions deaths in the world per year. Particularly in these countries, where the uncontrolled urban development due to the presence of several industrial plants in very small areas around which, population generally congregates for either their works or commercial purposes let them pay the heaviest price in this situation (WHO, 1987 [6]; WHO, 2000 [7]). Unfortunately the lack of air quality monitoring network in Africa has prompted the use of the numerical modeling by researchers. It has been proven that numerical models furnish acceptable results when studying atmospheric phenomena including air pollutants transportation, in predicting the outdoor spatial and temporal variations of pollutants and its behavior through mathematical algorithms that take into account atmospheric dispersion, chemical and physical processes in an attempt to approximate the concentrations of pollutants (Bin Zou, 2010 [8]). The aim of this work is to simulate the dispersion of the $\mathrm{PM}_{2.5}, \mathrm{CO}, \mathrm{NO}_{\mathrm{x}}$ and $\mathrm{SO}_{2}$ pollutants emitted at the Logbaba thermal power plant in Douala. To estimate the concentration of these pollutants, we used American Environmental Regulatory MODel (AERMOD) that is an ideal tool to many African countries facing the problem of in-situ data collection. AERMOD has a special ability to run with minimally observed meteorological parameters. In fact, it has been reported that it only requires a single surface measurement of wind speed, air temperature at screen height and total cloud cover (Holtslag, 1983 [9]). 


\section{Materials and Methods}

\subsection{Pollutants Selecting}

The urban atmospheric pollutants affecting the city of Douala include $\mathrm{PM}_{2.5}, \mathrm{CO}$, $\mathrm{NO}_{\mathrm{x}}$ and $\mathrm{SO}_{2}$. They are either related to the quality of the petroleum products used in the transportation industry or the emissions from existing industrial plants.

\subsubsection{Fine Particles ( $\left.\mathrm{PM}_{2.5}\right)$}

It refers to a complex mixture of carbonaceous particles with diameter less than $2.5 \mu \mathrm{m}$ (Debrock et al., 2009 [10]) and which result either from anthropogenic and natural mixture of primary and secondary aerosols (Bashurova et al. 1991 [11]; Spurny 1996 [12]; Karanasiou, 2007 [13]) or from the condensation of hot vapors emanating from the combustion of organic matter, biomass and liquid droplets. $\mathrm{PM}_{2.5}$ is known to have a negative impact on human health. In fact, they are a common culprit for respiratory tract irritation, increase frequency and intensity of asthmatic attacks, cardiovascular and lung diseases, even premature death (Risom et al., 2005 [14]; Ostro et al., 2006 [15]; Bräuner et al., 2007 [16]; Simkhovitch et al., 2008 [17]; IBGE-BIM, 2008 [18]; Liu et al., 2013 [19]; Al Moustafa et al., 2016 [20]). Moreover, they are responsible for the degradation of estates and architectural heritage (MIRA, 2007 [21]) through a thin layer deposition mechanism which occurs whenever their mean concentration exceeds the threshold value of $25 \mu \mathrm{g} / \mathrm{m}^{3}$ per 24 hours and $10 \mu \mathrm{g} / \mathrm{m}^{3}$ per annum (MMK, 2009 [22]) set by the WHO.

\subsubsection{Carbon Monoxide (CO)}

Carbon monoxide is both a product of incomplete hydrocarbon combustion and an important element of the atmospheric chemical process as shown in Equation (1).

$$
\mathrm{CO}+\mathrm{O}_{2}+\mathrm{NO} \rightarrow \mathrm{NO}_{2}+\mathrm{CO}_{2}
$$

Based on this equation, the reaction between $\mathrm{CO}, \mathrm{NO}$ and $\mathrm{O}_{2}$ produces carbon dioxide $\left(\mathrm{CO}_{2}\right)$ which is a greenhouse gas. $\mathrm{NO}_{2}$ is not only a pollutant, but also a health hazard (Clark et al., 2014 [23]). Consequently, CO has an adverse effect on both the central nervous system and other sensory organs. The threat of $\mathrm{CO}$ is so important that its accepted mean threshold value is set by WHO as low as $10 \mathrm{mg} / \mathrm{m}^{3}$ for 8 hours and $30 \mathrm{mg} / \mathrm{m}^{3}$ for an hour. An average of 8 hours is used for the evaluation of the allowed $\mathrm{CO}$ concentration in order to control its binding ability with haemoglobin forming carboxyhaemoglobin which is slowly released in the blood stream until an equilibrium level is reached between 6 and 8 hours (Sportisse, 2004 [5]).

\subsubsection{Nitrogen Compounds}

The urban atmospheric nitrogen compounds which exist in the form of nitrogen oxide (NO) and nitrogen dioxide $\left(\mathrm{NO}_{2}\right)$, generally originate from the transportation industry as well as other large energy-intensive sectors such as thermal plants 
(Sheel et al., 2010 [24]; Fourmeaux et al., 2000 [25]). Nitrogen compounds generally cause ozone depletion following the schema proposed in Equations (2) and (3) below.

$$
\begin{gathered}
\mathrm{CH}_{4}+\mathrm{NO}_{\mathrm{x}} \rightarrow \mathrm{CO}_{2}+5 \mathrm{O}_{3}+2 \mathrm{OH} \\
\mathrm{NO}+\mathrm{O}_{3} \rightarrow \mathrm{NO}_{2}+\mathrm{O}_{2}
\end{gathered}
$$

In fact, a high concentration of $\mathrm{NO}_{\mathrm{x}}$ leads to the ozone production in the troposphere (He et al., 2013 [26]), while a low concentration of $\mathrm{NO}_{\mathrm{x}}(\mathrm{NO})$ leads to the ozone depletion and $\mathrm{NO}_{2}$ production (Portmann et al., 2012 [27]; Arnold, 2004 [28]; and Seinfeld et al., 1997 [29]).

The chemical reactions of Equations (2) and (3) indicate the importance of atmospheric nitrogen molecules, either in the emission of greenhouse gases $\left(\mathrm{CO}_{2}\right.$ and $\left.\mathrm{O}_{3}\right)$ or the production of air pollutants $\left(\mathrm{NO}_{2}\right)$ (Aneja et al., 1996 [30]). Usually, the concentrations of $\mathrm{NO}$ in the ambient air are considered non-toxic, thus the reason why it is not subject to any restrictive standard (Fourmeaux et al., 2000 [25]). In the opposite, $\mathrm{NO}_{2}$ negatively affects the respiratory tract due to its high penetrating ability in the lungs (Fourmeaux et al., 2000 [25]). Consequently, the mean standard threshold values for $\mathrm{NO}_{2}$ are $200 \mu \mathrm{g} / \mathrm{m}^{3}$ per 1 hour and $40 \mu \mathrm{g} / \mathrm{m}^{3}$ per annum.

\subsubsection{Sulfur Dioxide ( $\left.\mathrm{SO}_{2}\right)$}

Sulfur dioxide is a colorless gas with a pungent characteristic odor, emitted during the combustion of coal as well as refined diesel and gasoil. As such, urban pollution with sulfur dioxide is influenced by industrial development. This compound is generally produced by an oxidation of the sulfur impurities. The standard mean threshold values are $20 \mu \mathrm{g} / \mathrm{m}^{3}$ per 24 hours and $500 \mu \mathrm{g} / \mathrm{m}^{3}$ for 10 minutes. Many studies have shown that a good proportion of asthmatic patients experience an impact of $\mathrm{SO}_{2}$ on both their pulmonary functions and their respiratory symptoms after only a 10 minutes exposure. In addition to the effects on the respiratory system and lung functions in the form of inflammation of the respiratory tract, an increased coughing, a mucus production and chronic bronchitis, sulfur dioxide is also responsible for eyes irritation.

\subsection{Description of the Study Area}

Geographical location of the Logbaba thermal power plant Logbaba is an eastern neighborhood of the city of Douala, located between $5 \mathrm{~m}$ and $13 \mathrm{~m}$ above sea level within the Gulf of Guinea, and which has an access to the Atlantic Ocean (Figure 1). Douala is especially exposed to air pollution being both an industrial and a densely populated city. Although the immediate vicinity of the thermal power plant investigated in this work is relatively flat, there are still small depressions in the field which are taken into account while modeling the atmospheric dispersion of its pollutants.

\section{Characteristics of the Source}

The Logbaba thermal power plant is made of units which operate using both 


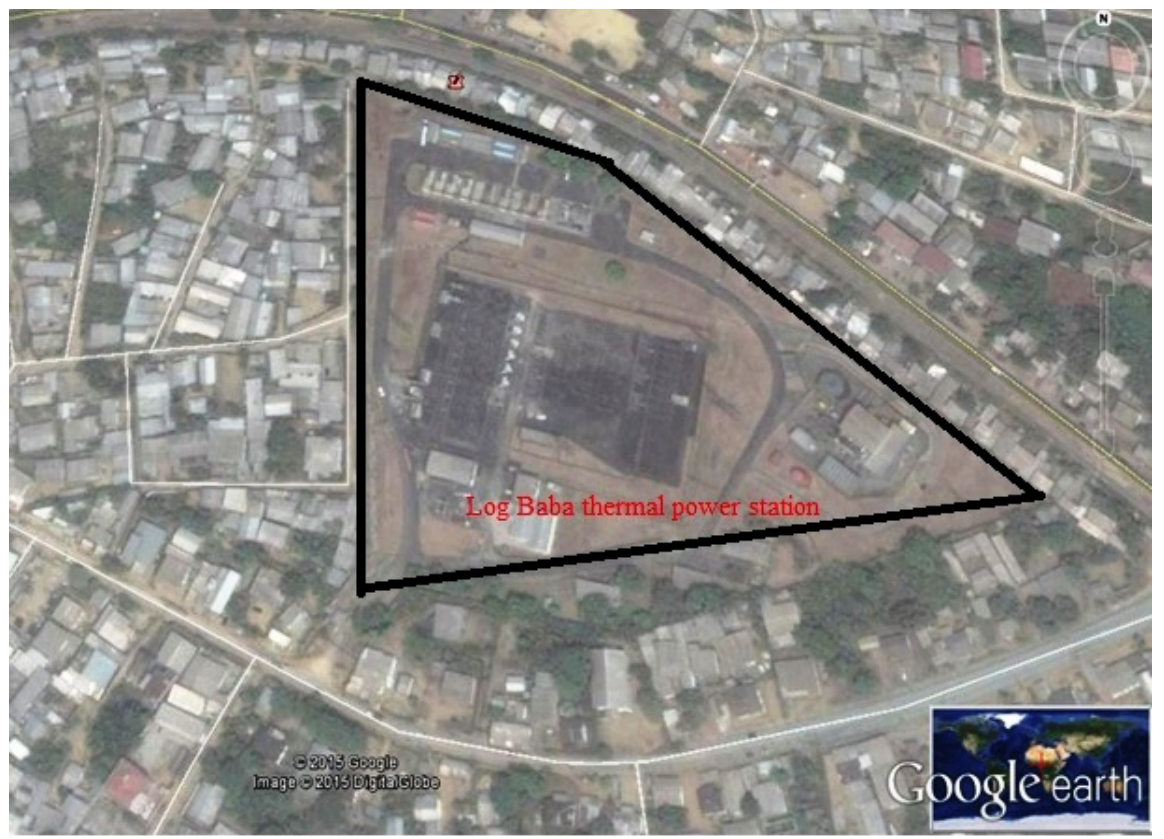

Figure 1. The Logbaba thermal power plant location.

Light Fuel Oil (LFO) and Heavy Fuel Oil (HFO). Some properties of the plants associated to each of the fuel type are provided by the manufacturer of its diesel engines and are reported in Table 1.

The weak effect resulting from specific weather conditions can lead to a downwash effect in the airflow upstream or downstream depending on the wind direction with respect to the buildings. An application of the mass balance equation to the plant shows an estimated annual average emission of $80 \%$ of the total power plant load. The $A_{0}$ and $A_{1}$ activities for HFO and LFO respectively, were evaluated based on the $\mathrm{NO}_{\mathrm{x}}$ emission rate of $24.70 \mu \mathrm{g} / \mathrm{m}^{3}$ provided by the services of the central Logbaba thermal power station. The resulting parameters are summarized in Table 2.

Based on the assumption that all the molecules of the same type ejected from the same plant have the same activities $A_{0}$ and $A_{1}$, the Equation (4):

$$
E=A \times E_{R} \times\left(1-\frac{F_{E}}{100}\right)
$$

was developed by U.S. EPA, using the basic principles of emission factors $\left(F_{E}\right)$ and the Tribal Emission Inventory Software Solution (TEISS) model (LESS, 1996-2015 [31]).

where: $E=$ Emission Rate,

$$
\begin{aligned}
& A=\text { Activity } \\
& F_{E}=\text { Emission Factor, } \\
& E_{R}=\text { Efficiency Reduction Percentage. }
\end{aligned}
$$

\subsection{Grid Construction}

The grid calculation points was built by considering that $220 \mathrm{~km}^{2}$ in the city of 
Table 1. Fuel characteristics used at the Logbaba thermal power plant.

\begin{tabular}{cccccccc}
\hline Fuel & Generators & $\begin{array}{c}\text { Power } \\
(\mathrm{W})\end{array}$ & $\begin{array}{c}\text { Total } \\
\text { Power } \\
(\mathrm{MW})\end{array}$ & $\begin{array}{c}\text { Calorific } \\
\text { Value } \\
(\mathrm{MJ} / \mathrm{Kg})\end{array}$ & $\begin{array}{c}\text { Specific } \\
\text { Gravity }\end{array}$ & $\begin{array}{c}\text { Specific } \\
\text { Consumption } \\
(\mathrm{M}) / \mathrm{kWh}\end{array}$ & $\begin{array}{c}\text { Efficiency } \\
(\%)\end{array}$ \\
\hline $\begin{array}{c}\text { LFO } \\
\text { (Light Fuel Oil) }\end{array}$ & 11 & 1.6 & 17.6 & 43.1 & 0.86 & 9.3 & 38.5 \\
$\begin{array}{c}\text { HFO } \\
\text { (Heavy Fuel Oil) }\end{array}$ & 2 & 6.5 & 13 & & & & \\
\hline
\end{tabular}

Table 2. Pollutants HFO and LFO activities.

\begin{tabular}{ccccccc}
\hline & \multicolumn{3}{c}{ HFO } & \multicolumn{3}{c}{ LFO } \\
\hline Activities (A) & \multicolumn{2}{c}{$\mathrm{A}_{0}=0.01723462 \times 10^{6}$} & \multicolumn{3}{c}{$\mathrm{A}_{1}=0.006342644$} \\
\hline Molecular Species & $\mathrm{SO}_{2}$ & $\mathrm{CO}$ & $\mathrm{PM}_{2.5}$ & $\mathrm{SO}_{2}$ & $\mathrm{CO}$ & $\mathrm{PM}_{2.5}$ \\
Factor Emission & 0.36 & 267.00 & 0.44 & 1.25 & 4.06 & 1.34 \\
$\quad \mathrm{~F}_{\mathrm{E}}(\mathrm{g} / \mathrm{kWh})$ & & & & & & \\
$\begin{array}{c}\text { Emission Rate } \\
\text { E }(\mathrm{g} / \mathrm{s})\end{array}$ & 1.28 & 953.02 & 1.57 & 1.64 & 5.33 & 1.76 \\
\hline
\end{tabular}

Douala out of a total of $1000 \mathrm{~km}^{2}$ is occupied by buildings and industries, justifying the need of additional points. In order to provide an optimal resolution in the vicinity of the source where the spatial concentration gradient is the highest, the mesh size was narrowed and stretched while walking away from the thermal power station.

The calculation grid points were further divided into two sectors. The first consists of the points found within $1 \mathrm{~km}$ of the plant and described by a meshing system of $100 \mathrm{~m} \times 100 \mathrm{~m}$ unit. The second consists of the points extending from 1 to $3.1 \mathrm{~km}$ after the plant and described by a meshing system of $150 \mathrm{~m} \times 150 \mathrm{~m}$ unit. Furthermore, two additional calculation points also known as point receivers were added for the representation of the concentrations in sensitive areas of the modeling domain, especially at the crossroads of Ndokoti located at $2.29 \mathrm{~km}$ west-north-west and the District Hospital of Logbaba located in the western part of the Logbaba thermal power plant.

\subsection{Meteorological Data}

The temperature, speed and direction of the wind soil data used for the simulation below 10 meters were the 5-year meteorological data (2008-2012). They were provided by National Oceanic Atmospheric Administration (NOAA) and prepared in conformity with the standard procedure for AERMET (MDDEP, 2005 [32]). In the case of wind parameters, the NOAA data were compared to those collected and supplied by the Agency for Aviation Safety in Africa and Madagascar (ASECNA), located at approximately $4.84 \mathrm{~km}$ (in a straight line) North-East and $39.06^{\circ}$ of the thermal power station. The wind rose data derived from both NOAA and ASECNA showed a good agreement. For the investigated period, the wind rose is presented in Figure 2. It shows that the dominant winds blow west-south-west (WSW), south 


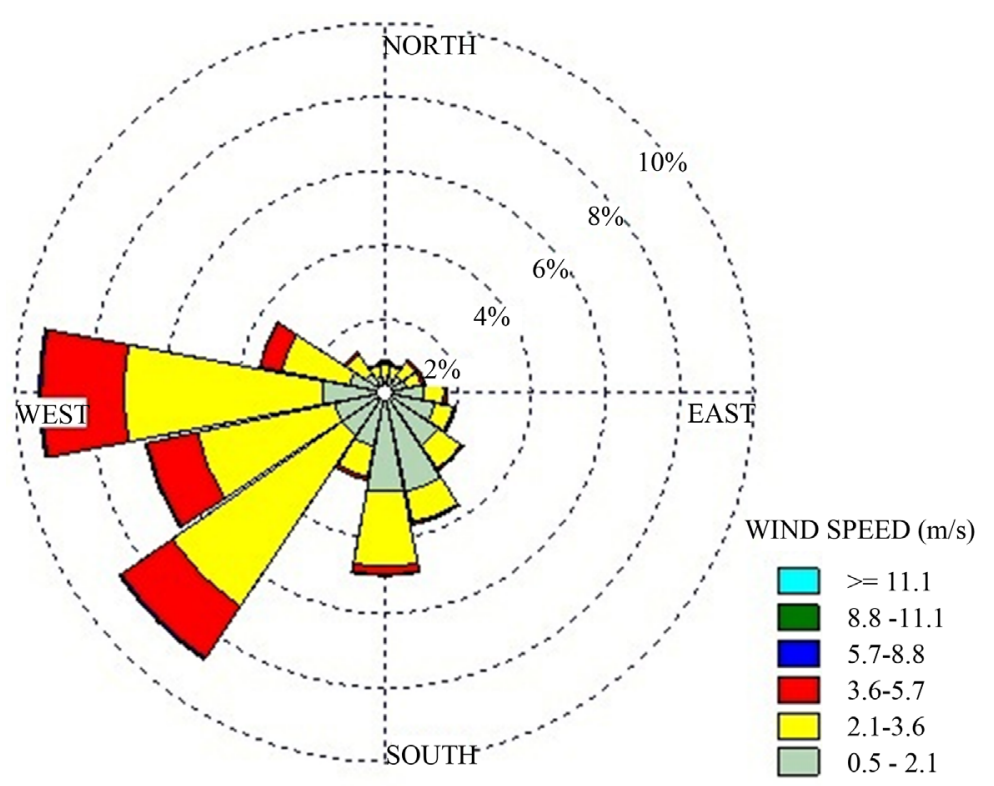

Figure 2. Wind rose derived from both ASECNA and NOAA data for the period of 2008-2012.

west (SW) and west (W) with frequencies of respectively $6.63 \%, 8.71 \%$ and of 9.34\%.

The main directions showed by the wind rose are consistent with the geographical location of the city of Douala with respect to the coastal side which directs the air movement. Therefore, the strong percentage of weak winds is found as $48.19 \%$ and can be explained by the geographical position of the city of Douala below the level of the gulf of Guinea. Moreover, the direction and intensities of the wind help explaining the dispersion of the pollutant as shown by the distribution of the iso-concentrations.

\section{Modeling and Results}

\subsection{AERMOD Model}

AERMOD is a near field and steady-state guideline model in that it assumes that concentrations at all distances during a modelled hour are governed by a set of hourly meteorological inputs, which are held constant (Cimorelli et al., 1998 [33]). Using available meteorological data and similarity theory scaling relationships associated with the geographical location of the Logbaba thermal power plant, we used AERMOD to construct hourly gridded vertical profiles of required meteorological variables. These variables include wind speed, wind direction, as well as vertical and horizontal turbulences, which are used to calculate plume rise, transport and dispersion of each plume as described by Perry (Perry et al., 2004 [34]).

The AERMOD modelling system consists of the model itself (AERMOD) and two stand-alone input data pre-processors: the meteorological pre-processor (AERMET) and the terrain pre-processor (AERMAP), described in Venkatram (Venkatram, 
2008 [35]). AERMET is used to provide meteorological data for organizing into a format suitable for use by the AERMOD, while AERMET is important for simulating the structure of the atmospheric boundary layer to estimate its depth and the dispersion of pollutants around the power plant. The meteorological data are used in conjunction with the surface characteristics such as roughness of the soil, small scale variation of surface topology, reflectivity (albedo) that describes the effect of the surface on the net incoming solar radiation (EPA, 2008 [36]), and Bowen's ratio ( $\beta$ ) that determines the moisture quantity available for evaporation.

In this study, the AERMET program is performed by recording only one year of in-situ available meterological parameters with the data provided in Table 3 and the surface data provided in the AERMOD meteorological pre-processor AERMET view version 8.2.0

The five-year meteorological parameters necessary for stability was first generated using AERMET followed by the calculation of the friction velocity $(u)$ that appears in the Convective Boundary Layer (Panofsky et al., 1984 [37]), the Monin-Obukhov length $(L)$ used to evaluate the Stable Boundary Layer (Venkatram, 1980 [38]), the convective velocity scale ( $W$ ) that takes into account the portion of the turbulence in the Convective Boundry Layer (Moen et al., 1988 [39]) and finally evaluates temperature scale $(\theta)$, mixed layer heights $\left(z_{i}\right)$ and the surface heat flux $(H)$ that are the Planetary Boundary Layer parameters.

These parameters were transferred to the interface with AERMOD, and used in conjunction with the similarity expressions to calculate different parameters such as the vertical profiles of wind speed $(u)$, the lateral and vertical turbulent fluctuations $\left(F_{v}, F_{w}\right)$, the potential temperature gradient $(\mathrm{d} \theta / \mathrm{d} z)$ and the potential temperature $(\theta)$. AERMAP uses gridded terrain data supplied in the Digital Elevation Model (DEM) format (USGS, 1994 [40]) for the computation of the representative influence heights $\left(h_{c}\right)$ of each receptor and source (EPA, 2004 [41]). The pre-processor computes both the terrain and critical hill height values for each receptor used as input into the AERMOD.

\subsection{Pollution Dispersion Modeling Maintaining}

The dispersion of $\mathrm{PM}_{2.5}, \mathrm{CO}, \mathrm{NO}_{\mathrm{x}}$ and $\mathrm{SO}_{2}$ was modeled under normal operating conditions in terms of pollutant release. Assuming that the power plant is operational all year round, the emission rates under these conditions were calculated as average of the measurements taken during the year.

Table 3. Type of land used.

\begin{tabular}{cccc}
\hline Scenario & Surface roughness & Bowen ratio & Albedo \\
\hline Dry season & 1 & 3.00 & 0.2075 \\
Wet season & 1 & 0.750 & 0.2075 \\
Annual average & 1 & 1.625 & 0.2075 \\
\hline
\end{tabular}




\section{Iso-Concentration Curves}

The iso-concentration curves are plotted for an hour, one day and one year. These curves were derived from the model computation for each hour. The concentration of a given pollutant was considered at all grid points while only the highest of the 43,824-hour (05 years) measurements of the broadcasting time was retained. The iso-concentration time curve at each grid point was then generated. These concentrations are not necessarily produced at the same time and do not represent the effect of emissions at a specific time; only cases of extreme pollution were taken into account during the 5-year study period. On the Figures 3-5 are plotted the iso-concentration curves of the pollutants computed over an hour, one day and one year respectively.
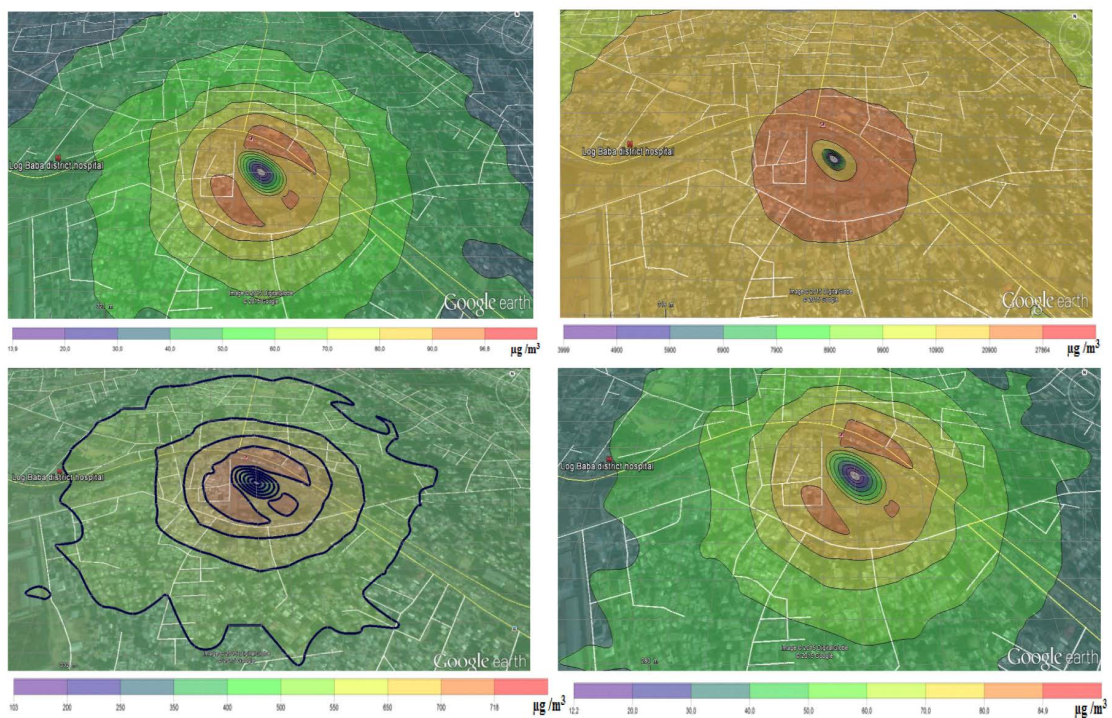

Figure 3. Hourly iso-concentration curves of $\mathrm{PM}_{2.5}, \mathrm{CO}, \mathrm{NO}_{\mathrm{x}}$ and $\mathrm{SO}_{2}$ respectively.
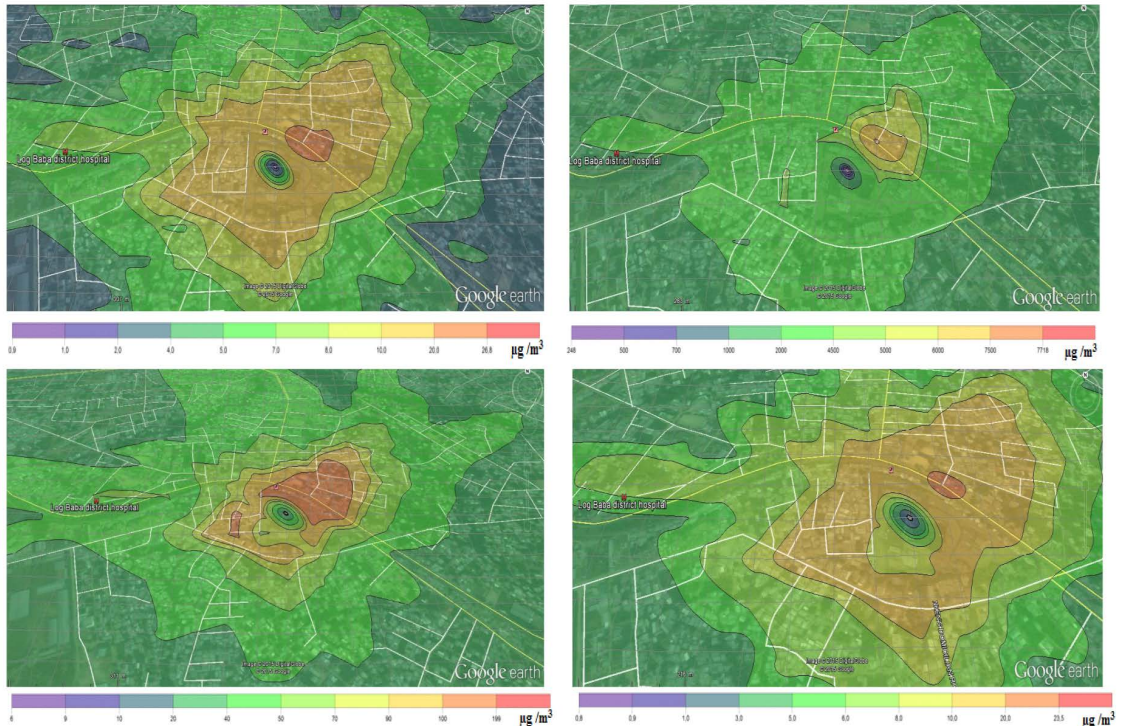

Figure 4. Daily iso-concentration curves of $\mathrm{PM}_{2.5}, \mathrm{CO}, \mathrm{NO}_{\mathrm{x}}$ and $\mathrm{SO}_{2}$ respectively. 


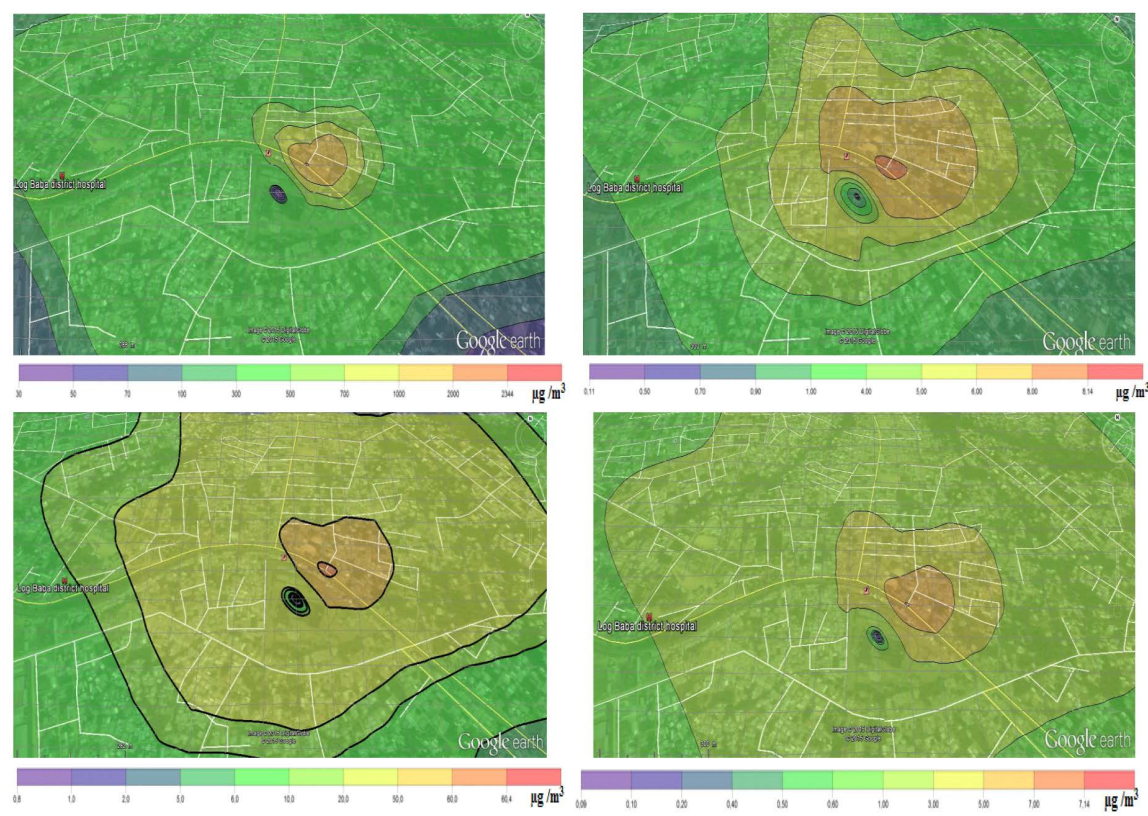

Figure 5. Annual iso-concentration curves of $\mathrm{PM}_{2.5}, \mathrm{CO}, \mathrm{NO}_{\mathrm{x}}$ and $\mathrm{SO}_{2}$ respectively rate to 2008-2012 period.

Following, daily iso-concentration curves were derived from the model computation at each grid point followed by a calculation of their average over a day. Only the highest average of the 1826-day study period was retained. Figure 4 shows the daily iso-concentration curves of the pollutants.

The process used to draw the annual iso-concentration curves was slightly different. In fact, the AERMOD model computes the average of all hourly concentrations modeled over the five years (43,824 hours), and then connects the points of same concentration. In this case, no maximum value is retained to calculate the annual average at a given point. Figure 5 shows the annual iso-concentration curves of pollutants.

\subsection{Evaluation of Each Pollutant Concentration}

The concentrations at the point of maximal impact obtained by AERMOD and shown in Table 4 for each contaminant are compared with the reference air quality values provided by the World Health Organization (WHO). $L_{V}$ and $C_{V}$ denote the WHO limit value in $\left(\mu \mathrm{g} / \mathrm{m}^{3}\right)$ and the calculated value in $\left(\mu \mathrm{g} / \mathrm{m}^{3}\right)$, and $R_{C}$ denotes the respect of criteria.

In the case of sulfur dioxide, the air quality limit value of the concentration below an hour is computed from Equation (5) (Leduc, 2004 [42]), where $T$ is the period expressed in hour and $C_{1 \text { hour }}$ is the maximum concentration over one hour.

$$
C(T)=C_{1 \text { hour }} \times 0.97 T^{-0.25}
$$

The Relative Concentration $C_{R}$

A better appreciation of the air quality with respect to each pollutant was done 
Table 4. Comparison between the calculated and the WHO limit value concentrations.

\begin{tabular}{cccccccccccccc}
\hline Pollutants & \multicolumn{3}{c}{$\mathrm{PM}_{2.5}$} & \multicolumn{4}{c}{$\mathrm{CO}$} & \multicolumn{3}{c}{$\mathrm{NO}_{\mathrm{x}}$} & \multicolumn{3}{c}{$\mathrm{SO}_{2}$} \\
\hline Concentrations $\left(\mu \mathrm{g} / \mathrm{m}^{3}\right)$ & $\mathrm{L}_{\mathrm{V}}$ & $\mathrm{C}_{\mathrm{V}}$ & $\mathrm{R}_{\mathrm{C}}$ & $\mathrm{L}_{\mathrm{V}}$ & $\mathrm{C}_{\mathrm{V}}$ & $\mathrm{R}_{\mathrm{C}}$ & $\mathrm{L}_{\mathrm{V}}$ & $\mathrm{C}_{\mathrm{V}}$ & $\mathrm{R}_{\mathrm{C}}$ & $\mathrm{L}_{\mathrm{V}}$ & $\mathrm{C}_{\mathrm{V}}$ & $\mathrm{R}_{\mathrm{C}}$ \\
\hline 10 minutes & - & - & - & - & - & - & - & - & - & 0.50 & 0.13 & yes \\
01 hour & - & - & - & 30 & 27.86 & yes & 0.20 & 0.72 & no & & & \\
08 hours & - & - & & 10 & 14.60 & no & - & - & & & & \\
24 hours & 25 & 26.8 & no & - & - & & & - & & 0.020 & 0.024 & no \\
01 year & 10 & 8.1 & yes & - & - & & 0.04 & 0.06 & no & & & \\
\hline
\end{tabular}

by plotting the relative concentration $\left(C_{R}\right)$, defined by Equation (6) as the ratio of the concentrations calculated by AERMOD $\left(C_{c a l}=C_{c}\right)$ and the reference values provided by $\mathrm{WHO}\left(C_{\mathrm{WHO}}=C_{L}\right)$.

$$
C_{R}=\frac{C_{c a l}}{C_{\mathrm{WHO}}}=\frac{C_{c}}{C_{L}}
$$

Among all the curves that could be plotted for the pollutants studied in this work, taking into account the lifetime and their dispersion in the air, we selected and show in Figures 6-8 the curves of the pollutants that have a real effect on the healthy cause of their relative concentration $R_{C}$ that is greater than one at the immediate vicinity of the thermal plant.

In these plots, the variation indicates the polluting effect of each species. In this context, $C_{R}>1$ indicates a highly polluting species. Beyond the distance of $330 \mathrm{~m}$ where the first houses are located, the air quality is quasi normal $\left(C_{R}<1\right)$ with respect to the species investigated. On the other hand, $\mathrm{NO}_{\mathrm{x}}$ annual rates are 3.6 and 1.5 times higher at the top of the thermal power and at the distance of $300 \mathrm{~m}$ respectively.

\subsection{Dispersion}

For a better appreciation of the dispersion we opt to determine the period of the day of high air pollution due to the presence of the Logbaba thermal plant. For that, we first selected the 50 hours of highest pollution out of the 43,824 hours analyzed by AERMOD. That was followed by their distribution according to their time of occurrence during the day. The results of this analysis such as presented in Figure 9(a) show that about 30 hours over the 50 hours of the highest pollution lie between 7:00 and 9:00 while the remain 20 hours representing the weak pollution peak appears first between 1:00 and 2:00 and secondly between 18:00 and 22:00. Furthermore, a plot of the curves showing the wind speed variations with the period of the day given in Figure 9(b) indicates a good correlation between the periods of high wind speeds and the periods of almost no pollution. Such observation is justifiable by the phenomenon of pollutant dispersion caused by air transportation.

\section{Particular Receptors}

These receptors are located at respectively the source which is the origin, the first 


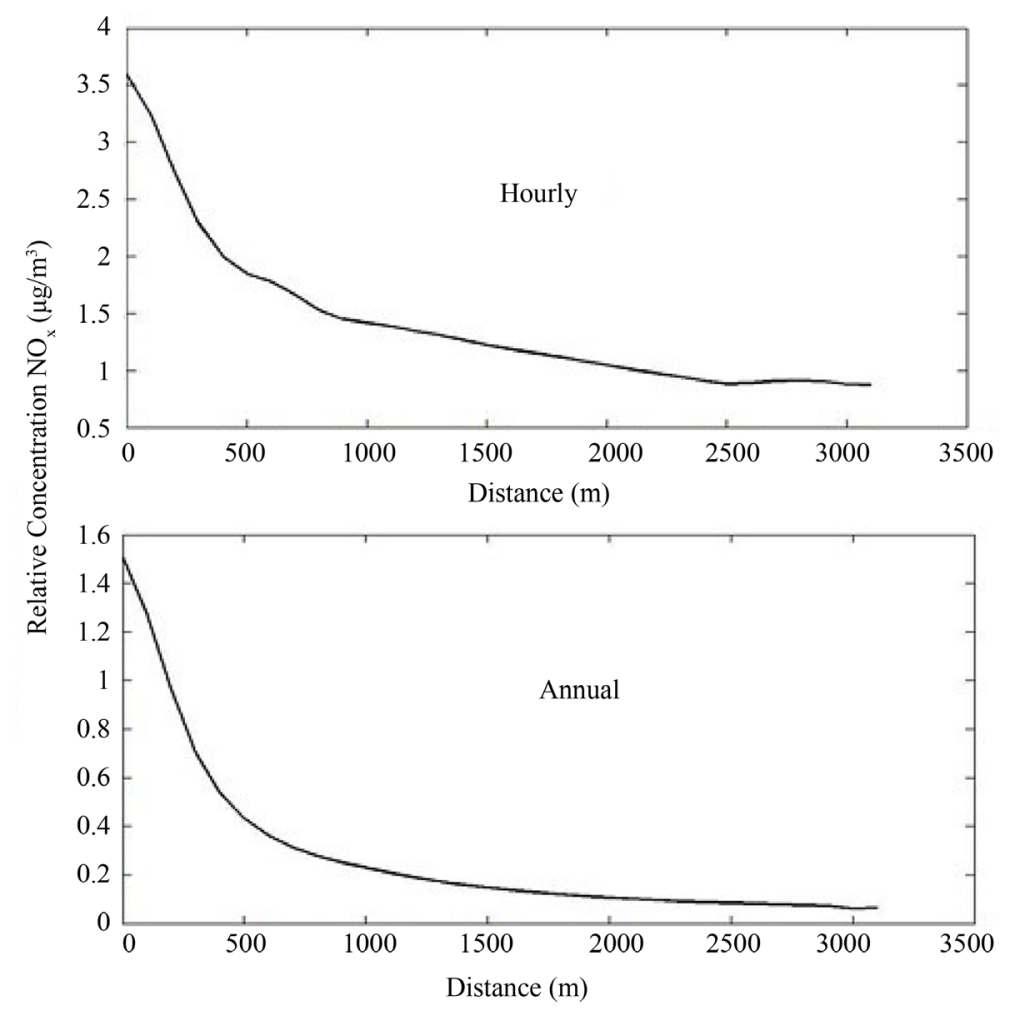

Figure 6. Hourly and annual $\mathrm{NO}_{\mathrm{x}}$ curves of relative concentration $\mathrm{R}_{\mathrm{C}}$, respectively.

residences at $330 \mathrm{~m}$ west, the Logababa district hospital at $770 \mathrm{~m}$ west and the Ndokoti crossroads at $2.29 \mathrm{~km}$ west-north-west of the thermal power station. These points represent the locations where a few hundred people can be found all day long. The variation of the pollutant concentrations at those locations is given in Table 5.

\subsection{Interpretation}

An examination of the iso-concentration plots can highlight a number of interesting facts. Indeed, Figures 4-6 which respectively represent the iso-concentration curves of the pollutants for an hour, one day and one year indicate that their dispersion is strongly oriented in areas west-south-west, southwest and west, in good agreement with the dominant winds as shown by the wind rose in Figure 3. Additionally, the highest annual iso-concentrations occur at a distance of 330 meters east of the thermal power plant. Moreover, a quick decrease of the concentration was observed with the distance from the plant. Finally, a drop of at least $35 \%$ of the annual concentrations was observed with respect to the highest annual concentration after the nearest residences to the thermal power plant. However, the concentration decreased by over $85 \%$ in the direction which is less affected by the emissions from the plant.

An evaluation of the pollution with respect to time and concentration indicates that all the investigated species show some polluting effect in time, in particular $\mathrm{NO}_{\mathrm{x}}$ which is most often emitted from the Logbaba plant. A comparison 


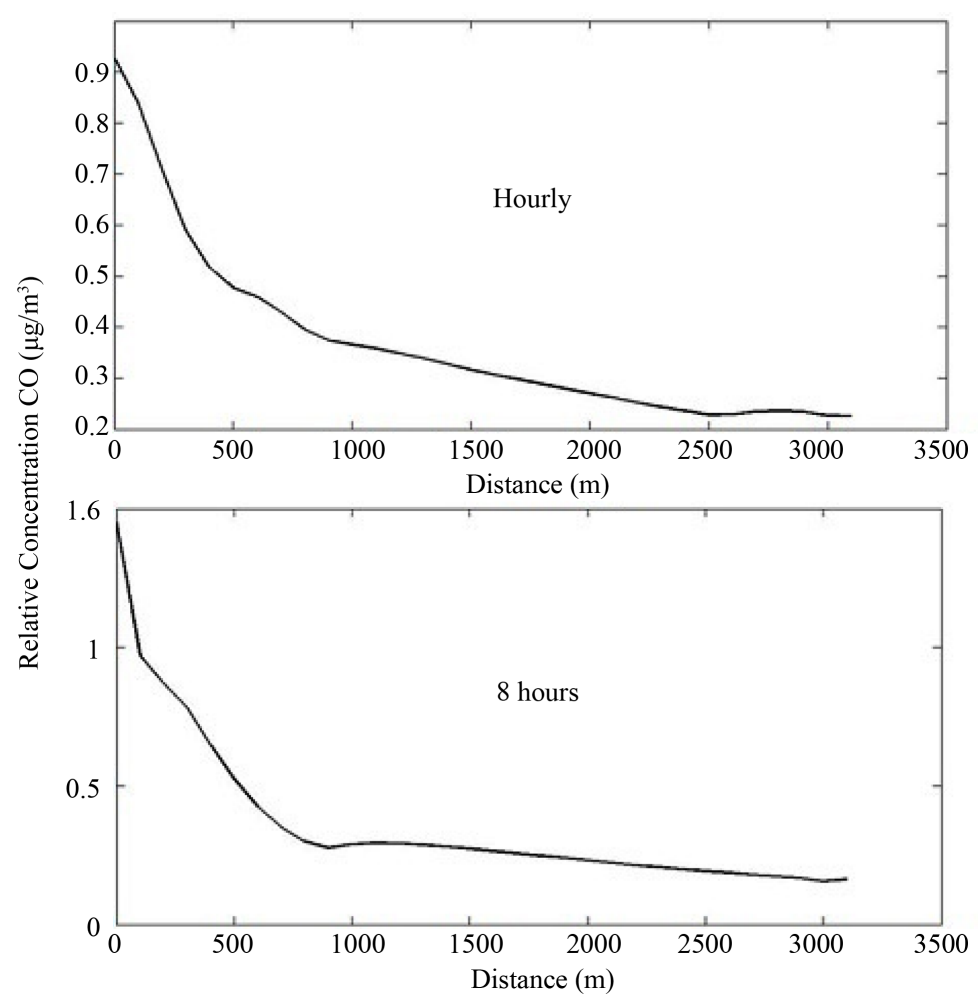

Figure 7. Hourly and 8 hours $\mathrm{CO}$ curves of relative concentration $C_{R}$, respectively.

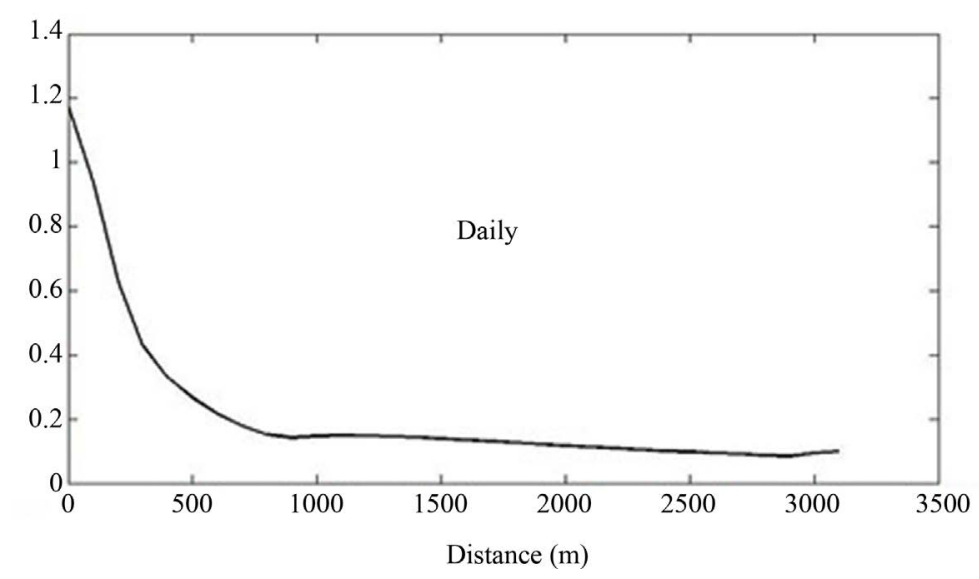

Figure 8. Hourly and annual $\mathrm{PM}_{2.5}$ curves of relative concentration $C_{R}$, respectively.

Table 5. Concentration of the pollutants in $\mu \mathrm{g} / \mathrm{m}^{3}$ at particular locations.

\begin{tabular}{ccccccccc}
\hline \multirow{2}{*}{ Locations } & \multicolumn{2}{c}{$\mathrm{PM}_{2.5}$} & \multicolumn{2}{c}{$\mathrm{CO}$} & \multicolumn{2}{c}{$\mathrm{NO}_{\mathrm{x}}$} & \multicolumn{2}{c}{$\mathrm{SO}_{2}$} \\
\cline { 2 - 9 } & 24 hours & 01 year & 01 hour & 08 hours & 01 hour & 01 year & $10 \mathrm{mn}$ & 24 hours \\
\hline Thermal plant & 26.8 & 8.1 & 27864 & 14596 & 718.2 & 60.4 & 128.9 & 23.5 \\
First residence & 9.8 & 3.8 & 17742 & 7841 & 457.3 & 28.1 & 82.1 & 8.6 \\
Logbaba hospital & 7.7 & 1.9 & 17568 & 5244 & 452.8 & 14.2 & 70.7 & 6.8 \\
N'dokoti crossroads & 4.2 & 1.2 & 11166 & 3582 & 287.8 & 8.9 & 51.7 & 3.8 \\
\hline
\end{tabular}




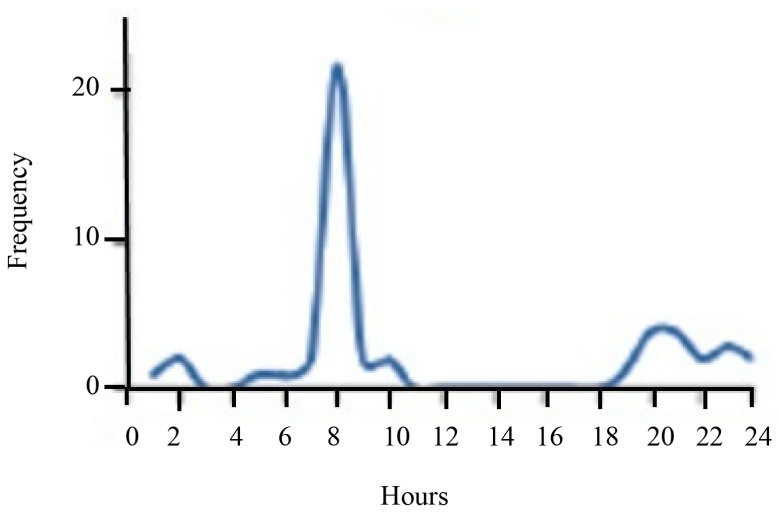

(a)

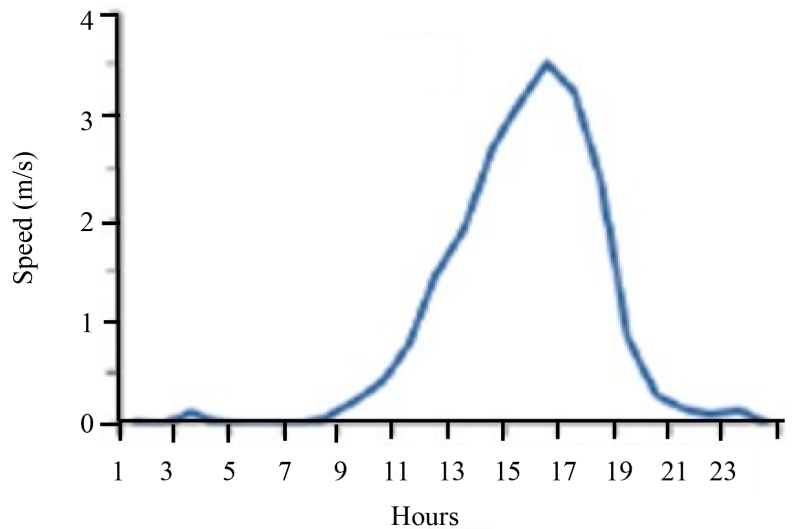

(b)

Figure 9. (a) Variation of the pollutant; and (b) Wind speed distribution over 24 hours. Frequency over 24 hours.

of the pollution periods and the wind distribution shows that periods of strong pollution are in fact associated to winds of negligible speed. The mean air velocity is $2.03 \mathrm{~m} / \mathrm{s}$ during its active period found between 9:00 and 18:00, with a maximum of $3.52 \mathrm{~m} / \mathrm{s}$.

\section{Conclusions and Recommendations}

The AERMOD atmospheric dispersion model is shown to be appropriate in the description of the atmospheric pollutants dispersion from the Logbaba thermal power plant. The resulting concentrations of $\mathrm{PM}_{2.5}, \mathrm{CO}_{2}, \mathrm{NO}_{\mathrm{x}}$ and $\mathrm{SO}_{2}$ were relatively higher near the power plant and consistently decreased as a function of the inverse of the distance from the source. This study shows that $\mathrm{NO}_{\mathrm{x}}$ is a dominant pollutant owing to its strong and permanent concentration in the atmosphere. However, the reliability of our results can be improved by carrying out further investigations with in-situ measurements at the level of the Logbaba thermal power plant. Such investigation will improve the model by enabling the comparison of the output values with those simulated by AERMOD.

A further investigation could address the harmful effects of these pollutants on human health in the region, in particular $\mathrm{NO}_{\mathrm{x}}$ as its coexistence with haze can 
reduce the environmental capacity for $\mathrm{SO}_{2}$; this would lead to a rapid conversion of $\mathrm{SO}_{2}$ to sulfate, because $\mathrm{NO}_{2}$ and $\mathrm{SO}_{2}$ have a synergistic effect when they react, for example on the surface of mineral (He et al., 2014 [43]). Indeed, occupational exposure to mineral dust is a significant cause of disability, morbidity and mortality. It is well established that pneumoconiosis (the fibrotic reaction of pulmonary tissue to retained dust) is one of the major debilitating outcomes of such exposure. Other health problems including chronic bronchitis and emphysema (Omland et al., 2014 [44]), pleural fibrosis (Rangelov et al., 2014 [45]), and certain cancers (Alazzam et al., 2010 [46]), as well as increased risk of tuberculosis (Salvi et al., 2009 [47]) are also associated with exposure to mineral dusts. In developing countries, people affected by these diseases can go undiagnosed and untreated. Moreover, a lack of awareness of such problem results in a lack of effective preventive measures. An investigation of these issues will therefore enable the decision makers to formulate effective policies for both the environment and public health protection. This will lead to social benefit by reducing respiratory diseases, and enable savings in the health care costs associated with air pollution.

\section{Acknowledgements}

This work was conducted under the UNESCO-HP Brain Gain initiative. The authors express their gratitude to AirMet Sciences and Dr. J. Thé of Lakes Environmental who provided AERMOD.

\section{References}

[1] Bünger, J., Krahl, J., Schröder, O., Schmidt, L. and Westphal, G.A. (2012) Potential Hazards Associated with Combustion of Bio-Derived versus Petroleum-Derived Diesel Fuel. Critical Reviews in Toxicology, 42, 732-750. https://doi.org/10.3109/10408444.2012.710194

[2] Olsson, P.Q. and Benner, R.L. (1999) Atmospheric Chemistry and Physics: From Air Pollutant to Climate Change. Wiley, Hoboken.

[3] Bell, M.L., Samet, J.M. and Dominici, F. (2004) Time-Series Studies of Particulate Matter. Annual Review of Public Health, 25, 247-280. https://doi.org/10.1146/annurev.publhealth.25.102802.124329

[4] Deok-Rae, K., Jae-Bum, L., Chang, K.S., Seung-Yeon, K., Young-II, M., Kyung-Mi, L., Jun-Seok, C. and Sang-Deok, L. (2015) Temporal and Spatial Distribution of Tropospheric $\mathrm{NO}_{2}$, over Northeast Asia Using OMI Data during the Years 2005-2010. Atmospheric Pollution Research, 6, 768-777.https://doi.org/10.5094/APR.2015.085

[5] Sportisse, B. (2004) The Atmospheric Pollution Modeling: Centre of Teaching and Research in Atmospheric Environment. Common Laboratory EDF R\&D-ENPC.

[6] WHO (1987) Air Quality Guidelines for Europe. Publications régionales. Série européenne $\mathrm{N}^{\circ} 23$. Bureau régional de l'Organisation mondiale de la Santé pour l'Europe, Copenhague.

[7] WHO (2000) Air Quality Guidelines for Europe. Publications régionales. Série européenne $\mathrm{N}^{\circ} 91$. 2ème édition, Bureau régional de l'Organisation mondiale de la Santé pour l'Europe, Copenhague.

[8] Bin Zou, F. and Benjamin Zhan, J.G.W. (2010) Performance of AERMOD at Different Time Scales. Science Direct, 18, Article ID: 612623. 
https://doi.org/10.1016/j.simpat.2010.01.005

[9] Holtslag, A.A.M. and Van Ulden, A.P. (1983) A Simple Scheme for Daytime Estimate of the Surface Fluxes from Routine Weather Data. Journal of Applied Meteorology and Climatology, 22, 517-529. https://doi.org/10.1175/1520-0450(1983)022<0517:ASSFDE >2.0.CO;2

[10] Debrock, K., Cheymol, A. and Vanderstraten, P. (2009) Les données de l'IBGE : Particules fines $\mathrm{PM}_{10}, \mathrm{PM}_{2.5}, \mathrm{PM}_{1}, \mathrm{PM}_{0.1}$. [The IBGE Data: Particles Matters $\mathrm{PM}_{10}$, $\mathrm{PM}_{2.5}, \mathrm{PM}_{1}, \mathrm{PM}_{0.1}$. The Data of Environment Observatory.] Research Laboratory on Environment. Department of Air, Climate and Energy, 1-51.

[11] Bashurova, V.S., Koutzenogil, K.P., Pusep, A.Y. and Shokhirev, N.V. (1991) Determination of Atmospheric Aerosol Size Distribution Functions from Screen Diffusion Battery Data: Mathematical Aspects. Journal of Aerosol Science, 22, 373-388.

[12] Spurny, K.R. (1996) Aerosol Air Pollution Its Chemistry and Size Dependent Health Effects. Journal of Aerosol Science, 27, S473-S474.

[13] Karanasiou, A.A., Sitaras, I.E., Siskos, P.A. and Eleftheriadis, K. (2007) Size Distribution and Sources of Trace Metals and n-Alkanes in the Athens Urban Aerosols during Summer. Atmospheric Environment, 41, 2368-2381.

[14] Risom, L., Moller, P. and Loft, S. (2005) Oxidative Stress-Induced DNA Damage by Particulate Air Pollution. Mutation Research Fundamental and Molecular Mechanisms of Mutagenesis, 592, 119-137.

[15] Ostro, B., Broadwin, R., Green, S., Feng, W.Y. and Lipsett, M. (2006) Fine Particulate Air Pollution and Mortality in Nine California Countries: Results from Calfine. Environmental Health Perspectives, 114, 29-33. https://doi.org/10.1289/ehp.8335

[16] Bräuner, E.V., Forchhammer, L., Möller, P., Simonsen, J., Glasius, M., Wahlin, P. and Loft, S. (2007) Exposure to Ultrafine Particles from Ambient Air and Oxidative Stress-Induced DNA Damage. Environmental Health Perspectives, 115, 1177-1182. https://doi.org/10.1289/ehp.9984

[17] Simkhovich, B.Z., Kleinman, M.T. and Kloner, R.A. (2008) Air Pollution and Cardiovascular Injury. Epidemiology, Toxicology, and Mechanisms. Journal of the American College of Cardiology, 52, 719-726.

[18] IBGE-BIM (2008) Rapport sur les Incidences Environnementales du Plan d'urgence en cas de pics. [The Report Agenda Urgency of the Environmental Impacts in Case of Peaks.]

http://www.documentation.bruxellesenvironnement.be/RIE_pic_pollution_2008052 8_FR.PDF

[19] Liu, C., Ying, Z., Harkema, J., Sun, Q. and Rajagopalan, S. (2013) Epidemiological and Experimental Links between Air Pollution and Type 2 Diabetes. Toxicologic Pathology, 41, 361-373. https://doi.org/10.1177/0192623312464531

[20] Al Moustafa, A.E., Mfoumou, E., Roman, D.E., Nerguizian, V., Alazzam, A., Stiharu, I. and Yasmeen, A. (2016) Impact of Single-Walled Carbon Nanotubes on the Embryo: A Brief Review. International Journal of Nanomedicine, 11, 349-355. https://doi.org/10.2147/IJN.S96361

[21] MIRA (2007) Achtergronddocument Verspreiding van zwevend stof, 8 december 2007. [Background Paper Distribution of Fuel, 8 December 2007.] http://www.milieurapport.be/Upload/Main/MiraData/MIRAT/02_THEMAS/02_05 /AG_WEVEND_STOF.PDF

[22] MMK (2009) Medisch Milieukundigen bij de LOGO's, Fiche fijn stof. [Medical Engineers at the LOGOs, Fiche.] http://www.mmk.be/vrij.cfm?Id=194 
[23] Clark, L.P., Millet, D.B. and Marshall, J.D. (2014) National Patterns in Environmental Injustice and Inequality: Outdoor $\mathrm{NO}_{2}$ Air Pollution in the United States. PLoS ONE, 9, e94431. https://doi.org/10.1371/journal.pone.0094431

[24] Sheel, V., Richter, A. and Burrows, J.P. (2010) Comparison of Satellite Observed Trophospheric $\mathrm{NO}_{2}$ over India with Model Simulations. Atmospheric Environment, 44, 3314-3321.

[25] Fourmeaux, A., Ruscart, F. and Maquinay, J.C. (200) Réseau de mesure de la qualité de l'air en régime Wallonie. D.G.R.N.E. ISSeP. [The Air Quality Network Measurement in Wollonie. D.G.R.N.E. ISSeP.] http://environnement.wallonie.be

[26] He, H., Hembeck, L., Hosley, K.M., Canty, T.P., Salawitch, R.J. and Dickerson, R.R. (2013) High Ozone Concentrations on Hot Days: The Role of Electric Power Demand and NOx Emissions. Geophysical Research Letters, 40, 5291-5294. https://doi.org/10.1002/grl.50967

[27] Portmann, R.W., Daniel, J.S. and Ravishankara, A.R. (2012) Stratospheric Ozone Depletion Due to Nitrous Oxide: Influences of Other Gases. Philosophical Transactions of the Royal Society B, 367, 1256-1264. https://doi.org/10.1098/rstb.2011.0377

[28] Arnold, F. (2004) Impact sanitaire de la pollution atmosphérique urbaine. [The Health Impact Due to Urban Atmospheric Pollution Sanitaire.] Nature, 284, 640.

[29] Seinfeld, J.H. and Spyros, N.P. (1997) Atmospheric Chemistry and Physics: From Air Pollution to Climate Change Journal of the American Chemical Society, 121, 1423-1432. https://doi.org/10.1021/ja985605y

[30] Aneja, P., Kim, D.S., Das, M. and Hartsell, B.E. (1996) Measurements and Analysis of Reactive Nitrogen Species in the Rural Troposphere of Southeast United States: Southern Oxidant Study Site SONIA. Atmospheric Environment, 30, 649-992.

[31] LESS (1996-2015) Course Notes on AERMOD, Gaussian Plume, Air Dispersion Model. Lakes Environmental Software.

[32] MDDEP (2005) Guide de la modélisation de la dispersion atmosphérique. [Atmospheric Dispersion Modeling Guideline.] 32 p.

[33] Cimorelli, A.J., Perry, S.G., Venkatram, A., Weil, J.C., Paine, R.J., Wilson, R.J., Lee, R.F. and Peters, W.D. (1998) AERMOD Description of Model Formulation. Version 98314, USEPA, RTP, NC 27711, 113 p.

[34] Perry, S.G., Cimorelli, A.J., Paine, R.J., Brode, R.W., Weil, J.C., Venkatram, A., Wilson, R.B., Lee, R.F. and Peters, W.D. (2004) AERMOD: Dispersion Model for Industrial Source Application. Part II. Model Performance against 17 Field Study Databases. Journal of Applied Meteorology and Climatology, 44, 694-708. https://doi.org/10.1175/JAM2228.1

[35] Venkatram, A. (2008) Introduction to AERMOD. U. Bourns College of Engineering. University of California Riverside, 1-8. http://www.engr.ucr.edu/ venky/Introduction_AERMOD_2008\%20.pdf

[36] Garratt, J.R. (1992) The Atmospheric Boundary Layer. Cambridge University Press, New York.

[37] Panofsky, H.A. and Dutton, J.A. (1984) Atmospheric Turbulence: Models ANS Methods for Engineering Applications. Wiley.

[38] Venkatram, A. (1980) Estimating the Monin-Obukhov Lengh in the Stable Boundary Layer for Dispersion Calculation. Boundary-Layer Meteorology, 19, 4814-4854. https://doi.org/10.1007/BF00122347

[39] Moen, C. and Wingaard, J.C. (1988) Spectral Analysis of Large-Eddy Simulations of the Convective Boundary Layer. National Center for Atmospheric Research. 
[40] USGS (1994) The 1994 Plan for the National Spatial Data Infrastructure Building the Foundation of an Information Based Society. Federal Geographic Data Committee Report. U.S. Geological Survey, Reston, Internet World Wide Web HTML.

[41] EPA (2004) User's Guide for the Industrial Source Complex (ISC3) Dispersion Model. Revised Volume II Description of Model Algorithmes, EPA-454/b-95-0036.

[42] Leduc, R. (2004) Guide de modélisation de la dispersion atmosphérique. [Atmospheric Dispersion Modeling Guideline.] The Atmospheric Midst Service. Faun and Environment Department of Quebec.

[43] He, H., Wang, Y., Ma, Q., Ma, J., et al. (2014) Mineral Dust and $\mathrm{NO}_{\mathrm{x}}$ Promote the Conversion of $\mathrm{SO}_{2}$ to Sulfate in Heavy Pollution Days. Scientific Reports, 4, 4172. https://doi.org/10.1038/srep04172

[44] Omland, O., Wurtz, E.T., Aasen, T.B., Blanc, P., Brisman, J., Miller, M.R., Pedersen, O.F., Schlunssen, V., Sigsgaard, T., Ulrik, C.S. and Viskum, S. (2014) Occupational Chronic Obstructive Pulmonary Disease: A Systematic Literature Review. Scandinavian Journal of Work, Environment \& Health, 40, 19-35. https://doi.org/10.5271/sjweh.3400

[45] Rangelov, K. and Sethi, S. (2014) The First Described Case of Occupational Anthracofibrosis in the USA. Case Reports in Pulmonary, 2014, Article ID: 460594. https://doi.org/10.1155/2014/460594

[46] Alazzam, A., Mfoumou, E., Stiharu, I., Narayanswamy, S., Bhat, R., Darnel, A. and Al Moustafa, A.E. (2010) Identification of Deregulated Genes by Single Wall Carbon-Nanotubes in Human Normal Bronchial Epithelial Cells. Nanomedicine, 6, 563-569.

[47] Salvi, S.S. and Barnes, P.J. (2009) Chronic Obstructive Pulmonary Disease in Non-Smokers. The Lancet, 374, 733-743. 